\title{
Formation of Media Competence of Future Teachers by Means of ICT and Mobile Technologies
}

\author{
https://doi.org/10.3991/ijim.v13i11.11350 \\ Olga V. Galustyan $\left({ }^{\square}\right)$ \\ Southern Federal University, Rostov-on-Don, Russia \\ olga.galustyan@gmail.com \\ Natalia I. Vyunova \\ Voronezh State University, Voronezh, Russia. \\ Emilia P. Komarova, Elena S. Shusharina \\ Voronezh State Technical University, Voronezh, Russia. \\ Saida S. Gamisonija \\ Southern Federal University, Rostov-on-Don, Russia \\ Oksana N. Sklyarova \\ The Military Educational and Scientific Center of "The Air Force Academy named after \\ Zhukovsky N.E. and Gagarin Y.A.”, Voronezh, Russia

\begin{abstract}
The paper is devoted to the problem of formation of media competence of future teachers by means of ICT and mobile technologies. It discusses the concepts of media competence, media education and media culture. Motivational, cognitive, technological, reflective components within the structure of media competence are revealed in the article. The results of experimental work of formation of media competence of future teachers by means of ICT and mobile learning technologies are presented. The authors conclude that study of modern methodological and technological methods of media education, history of their emergence and development, creative use within the educational process opens new perspectives for the application of the educational and developmental potential of media education at school and universities.
\end{abstract}

Keywords - media competence, media education, multimedia tools, ICT, mobile technologies, teachers

\section{Introduction}

The most important task of modernization of education is development of professional competence of teachers, their skills and abilities of self-education, formation of readiness and ability of adaptation to the changing social, political and economic conditions [9, 10, 17]. 
A modern teacher is an expert who is oriented in the informational space freely, has necessary knowledge and skills to search, to store and to use information, to transform and to modify it, to work with various information tools, to use modern mobile technologies, computer communications and systems [26, 28, 33].

The significant aspect of informatization of education is immersion of teachers to the process of creative constructive activity by means of multimedia, their formation of skills of the use of media in their professional activities, and the ability to design their own multimedia environments by means of ICT and mobile learning technologies. Teacher should receive necessary knowledge and skills, form their individual creative aspects of the personality that determine vector of their further professional development [16, 22, 27].

Increasing influence of multimedia tools and technologies on the world educational space, as well as the need to change forms, methods and approaches of teacher training makes it important to study issues related to the development of media competence of a modern teacher aimed at improving the quality of training, education and development of students at different levels of education.

\section{$2 \quad$ Methodology}

Modern pupils and students are better oriented in the information space such as mobile technologies and Internet than their teachers and parents. This is a true trend in the development of the informational society. The task of teachers within the informational age is to develop the child's critical thinking, ability to analyze and to select personal meaningful information, to structure, to synthesize, to use and to create his / her own media texts for the information environment, which helps to form child's media culture. Media culture, on the one hand, is a part of the general culture which associated with the media of communication, and, on the other hand, is a part of general culture of a person. Teacher should begin with the formation of his / her own media competence, which is aimed at the formation of the media culture of a modern teenager $[4,7]$.

Media such as satellite, digital TV, video, cinema, computer and cellular communications, Internet, graphics, music, radio, etc., transform the media environment, have a significant impact on traditional types of culture, on the functioning of libraries, film studios, museums, theaters, etc. Media culture affects the values of society, the worldview of different social and cultural groups while is being a phenomenon of the era of globalization [14, 21,29].

The process of forming media culture consists of many components such as study of mobile technologies and masterpieces of the world culture, study of color and sound harmony, laws of visual perception, technology of creating a "screen image" and the others.

Lifelong learning is one of the basic principles, without which a modern teacher cannot keep up with the development of the global information community. The development of media competence of a teacher is an essential factor which influences the formation of his / her media culture. Formation of professional competence of 
teachers relates to ensuring their full preparation for using media in the educational process.

Media education is understood by $[13,19,32]$ as the process of education and personal development with the help of media and on the media material in order to form a culture of communication, creative, communication skills, critical thinking, skills of interpretation, analysis and evaluation of various information, various selfexpression using modern mobile and digital technologies.

The term "media competence" is considered by $[2,12,20]$ as an individual's ability to interact, to process and to analyze media. Media competence is proposed as the main goal of media education.

Media competence is also characterized as a propensity for qualified, independent, creative, and socially responsible action in relation to media. Consequently, the development of media competence can be viewed as an activity aimed at the methodical processing of media texts, which is closely associated with the creative self-realization of one's personality $[15,18,30]$.

$[25,32]$ understand media competence as the ability to use, to analyze, to evaluate, and to transmit messages in various forms. Media competence is considered as the teacher's ability to dive into information and communication activities. This leads to the need to create a multimedia educational environment that carries out the relationship between the participants of the educational process.

$[23,24,31]$ consider the media literacy of a teacher as a complex of his / her motives, knowledge, skills, abilities that contribute to media education of the audience of various ages. Teacher's media competence should be improved on the basis of an integrated approach in media education, that means simultaneous study of several directions of media education (images, sound, photos, etc.) in their interrelationships.

$[13,19]$ write that integrated media education has a beneficial effect on teachers' professional success, their ability to conduct classes in the form of a dialogue, using more advanced learning mobile technologies. Media educators pay great attention to the media educational opportunities of Internet and mobile technologies, the impact of which on a person is considered to be very ambiguous. The ultimate goal of media education is not only to perceive media texts critically, but also to realize what role they play in the surrounding reality, to view media as a means of human selfexpression, as a means of cultural development, to evaluate how media texts influence the audience. Internet is not only the means of combining information, but also a kind of parallel reality in which a person undergoes changes, the very idea of the surrounding world is distorted. Therefore, it is necessary to help the teacher to form priorities in the use of new media in his / her professional activities for the effective upbringing of students in modern conditions.

Many researchers $[18,32]$ focus on the activity and creative aspect of personality of media educators. They define media competence as a structure which consist of ability to critical thinking, understanding the process of mass communication, ability to create one's own media texts and ability to analyze and to interpret media. $[13,32]$ consider that media competence is an integral part of communicative competence and is aimed at active contact with media resources. They identify creative media design as a key component of media competence, which creates a new media text. 


\section{$3 \quad$ Materials and Methods}

Formation of media competence of future teachers by means of ICT and mobile technologies was implemented with the help of the educational program "Media Competence of a Teacher within Digitalization of Education".

The program was based on practical theory of media education, theory of "critical thinking", which took into account professional and personal experience of each teacher. The program was designed for teachers who had basic computer skills and experience in using mobile and information and communication technologies in their professional activities.

The goal of the program was development of a teacher's media competence in creative constructive activities through the creation of a multimedia educational environment of a lesson using ICT and mobile learning technologies.

Realization of the program's goal involved the following tasks:

- Generalization and systematization of modern achievements of media education as a branch of pedagogical science;

- Mastering of modern pedagogical technologies for creating educational media;

- Study of modern pedagogical technologies and ICT and mobile learning technologies for creating a multimedia educational environment for using media texts within educational activities of teachers;

- Mastering the legal and aesthetic features for using media texts within professional pedagogical activity.

The solution of the assigned tasks was realized with the work on individual educational and methodical projects for a specific lesson, separate media texts of didactic purpose, creating of multimedia educational environment of the universal interactive hypertext space by means of ICT and mobile learning technologies.

- Teachers should know after mastering the program:

- Main directions, goals and objectives of media education;

Regulatory framework for the use of ICT and mobile learning technologies within their professional teaching activities;

- Typology of media texts, features of their search, creation, processing and integration into the multimedia environment;

- Key concepts of media education;

- Psychological, didactic, social and pedagogical problems of using media texts in practical activities by means of ICT and mobile learning technologies;

- Methods of mastering new media products by means of ICT and mobile learning technologies and to use them in their professional teaching activities;

- Technology of organization of personal information space taking into account the goals and objectives of media education;

- Methods of creating media texts for educational purposes and multimedia environment by means of ICT and mobile learning technologies. 
Teachers have to be able to:

- To be acquainted in a variety of media texts and to carry out their selection for educational purposes, to "read" media texts correctly;

- To carry out creative design activities, to create their own media texts by means of ICT and mobile learning technologies;

- To create a multimedia educational environment of various types based on the use of media objects for educational purposes;

- To introduce health saving technologies based on the use of media texts in educational activities.

The program is based on the following didactic principles:

- Practical orientation, connection with the specific problems of the teacher's professional activities in the media field;

- Focus on solving the problems that are important and personally significant for a particular teacher.

This program is based on the model of integrated training of specialists. The problem and modular principle is the basis for the building of the content of the program. Therefore, the curriculum and thematic plan includes topics of other areas of knowledge such as philosophy, pedagogy, psychology, etc.

The following training technologies were used within the process of implementing the program:

\subsection{Modular learning technology}

The program is based on this technology, which allows to use a variable component within the process of building and implementing of this program which is designed in such a way that allows to create a flexible educational space $[5,11]$.

\subsection{ICT and mobile learning technologies}

Teachers should use the following mobile and digital teaching aids while creating media texts and a multimedia educational environment:

- Video materials such as fragments of concerts, extra-curricular activities, etc.;

- Photographic materials such as illustrations, photographs, animated images that teacher uses to create educational media texts;

- Audio materials such as musical works, records of one's own voice for creating media texts of a methodical or didactic nature;

- Printed information such as electronic educational texts, from which further content of media texts is generated;

- Communication hypermedia. Principle of combining media texts into a single structure that allows to build a multimedia educational environment from individual media objects $[1,3,6]$. 


\subsection{Project technology}

Teachers are immersed in the project activities. It implies the choice of a project theme, form of a multimedia educational environment, quantity and quality of media texts that the teachers will develop and create independently. Formation of media competence of teachers is effective within the process of creating projects of various kinds $[8,25]$.

Individual, group, interactive forms of education are used while educational process is organized. Individual form of education implies consulting assistance to teachers throughout the program, provides methodological assistance. This form of education is especially important because it allows to establish contact with each participant, which contributes to the implementation of the personal-centered approach and the effective development of media competence of teachers.

Group forms of education imply the inclusion of each teacher in the process of interaction with the other participants, which allows to create conditions for revealing methodological, didactic and informational difficulties in creating media texts, exchanging views on the solution of certain problem.

Interactive forms of education are the most effective ones for the formation of media competence of teachers. These forms of education imply active interaction between all participants within the educational process by means of ICT and mobile learning technologies. Teachers are immersed in the process of creative constructive activity, self-realization of methodological plans when they create media texts.

The program includes four topics. Teachers have to carry out a project within each topic. Electronic Test is carried out showing the effectiveness of mastering the topic and the dynamics of the formation of media competence of teachers. Monitoring the development of media competence of teachers is carried out with the help of MyTests, which allows to create questions of various types such as single choice with one correct answer, multiple choice, assignment tasks for matching true and false answers.

The first topic is "Media Education and Media Creativity: Key Concepts and Main Directions".

This topic highlights the cognitive aspects of modern concepts of media education, examines the content of such concepts as "media art", "pedagogical creativity", "media competence", "media text", "multimedia tools", "multimedia technologies", "new media", "mobile learning technologies", "information and communication technologies", "multimedia educational environment", "media artistic forms of educational activity". A comparative analysis of multimedia tools, ICT and mobile learning technologies within the context of educational is carried out. Various media artistic forms of educational activities are considered. Classification of media texts and peculiarities of their use are demonstrated. This topic gives general ideas about multimedia educational environment and the basic principles of its design and content.

The second topic is "Search and methodical processing of media texts by means of ICT, mobile learning technologies and Internet".

This topic discusses general principles of building computer networks, features of using Internet as means of communication, the essence of "cloud" data processing and 
storage, their varieties, the main methods of working in "cloud". It is important to teach searching and processing of information in retrieval systems, encyclopedic and news portals, networks of pedagogical communities, regional educational portals.

Teachers work in network communities and portals independently within the process of learning. Practical classes of problematic nature, conversations, and consulting support are held at this stage.

The third theme is "Features of creating media text with Microsoft Office tools".

Teachers create media texts with the tools of the Microsoft Office program complex, WindowsLive film studio environment. They master interactive capabilities of the Microsoft Office program, examine typical mistakes when they create media texts by means of Microsoft Office within the process of fulfilling practical tasks.

Special attention is to be paid to the content of the media texts created by the teacher at this stage. The theme implements a variable component of the program. Teachers join the work that implements the activity stage of media competence as a result of media text design by means of Microsoft Office, Windows Movie Maker and Windows, Movie Maker. They analyze features of structuring, necessary material for further modeling.

Teacher analyze media texts not only by the degree of its practical applicability, but also by its aesthetic features and relevance of use of the chosen cover, which allows to state the development of practical, operational, creative and semantic indicators of media competence.

The fourth topic is "Features of creating media texts through network services".

The work is aimed at the creation of media texts by means of Web services and technologies Web 2.0.

Teachers study features of using media texts created by means of network services, convert media texts created earlier into a network service, and store media texts in Internet within the process of practical implementation of the individual project. Teachers learn the principles of web-resource design, features of the presentation of educational material in the network, basics of website building and creation of blogs, development of creative interactive and problem tasks using Learning Apps network service.

Implementation of the program provides conducting lectures and practical classes, during which discussions and analysis of media libraries take place, active forms of education, work in small groups, etc. are used. A special place is given to the implementation of practical activities for realization of an individual project.

The program provides conducting lectures in a multimedia demonstration class. Practical classes are used with the help of mobile technologies.

The program includes monitoring activities of teachers which allow to determine the level of formation of the media competence of each teacher.

Monitoring involves three diagnostics:

Input diagnostics: The goal is to determine the level of media competence of a teacher. Form of input diagnostics is testing.

Current evaluation: The goal is to determine success of teacher's achievement of the tasks set at the current stage. Form of current evaluation is a conversation concerning the results of the tasks of intermediate practical work, testing. 
Final evaluation: The goal is to determine the success of the teacher achieving the tasks of the program. Form of final evaluation is project, testing.

The following forms of evaluation were used within the process of experimental work:

- Electronic forms: tests which were created in My Test program, which allow to assess the level of development of media competence of teachers objectively and accurately, as well as to combine various ways of transmitting information (text, visual, audio);

- Individual forms: form of evaluation which is expressed in the form of consulting of the participants or a conversation that allows to assess the degree of understanding of theoretical material and skills within the use of multimedia tools, ICT and mobile technologies in the construction of various tasks;

- Frontal forms: a form of evaluation, which allows to use the survey to assess the degree of readiness of teachers to the perception and processing of information, the level of initial skills within the use of multimedia tools, ICT and mobile technologies;

- Interactive forms: forms of evaluation, which allow to assess the degree of mastering building media texts by means of multimedia tools, ICT and mobile technologies within the process of collective interaction. This form of evaluation allows to evaluate the results of their activities independently.

\section{$4 \quad$ Results}

Experimental work took place at three universities (Southern Federal University, (Rostov-on-Don), Voronezh State University (Voronezh), Voronezh State Technical University (Voronezh)) in 2018-2019. Students of these universities participated in the experimental work. We formed 2 groups (control group included 125 future teachers and experimental group consisted of 127 future teachers). 252 students participated in the study. Respondents were from 20 to 23 years of age.

Initial study was conducted to identify the initial level of media competence in the experimental and control groups at the beginning of the program. We have identified motivational, cognitive, technological, reflective components within the structure of media competence.

Motivational component is an integrative characteristic of a person, which is expressed in willingness and readiness of a teacher to study media texts of various genres and thematic spectrum with the inclusion of non-entertainment genres, to receive new information, to search for media materials for educational, scientific, research purpose; readiness to learn how to create media texts by oneself by means of ICT and mobile learning technologies studying specific examples of creativity of professionals.

Cognitive component is ability and willingness to perceive, to understand the content of the media text and filter out "noise"; ability to understand and to respect the power of media texts; ability to distinguish between emotional and reasoned reactions in the perception of media texts; knowledge of the specifics of language of different 
media and the ability to understand their impact regardless of the complexity of media texts.

Technological component includes ability to select and to use what media can offer, to develop your own media product by means of ICT and mobile learning technologies; practical skills of self-selection, the creation and distribution of media texts of various types and genres by means of ICT and mobile learning technologies (including created personally or as part of a group); skills of active self-education in the media field.

Reflective component is ability to analyze the process of functioning of media in society and media texts of different types and genres based on certain levels of development of media perception and critical thinking critically; ability to analyze media texts on the basis of media perception close to "complex identification"; ability to analyze and to synthesize space and time form of a media text, to understand, to interpret, to involve comparison, abstraction, induction, deduction, synthesis, critical assessment of the author's concept in context the structure of the work, historical and cultural contexts ( to express agreement or disagreement with the author's position of media text, a critical assessment of the moral, emotional, aesthetic, social significance of media text); ability to correlate emotional perception with conceptual judgment, to transfer this judgment to other genres / types of media culture, to link media text with one's own experience and the experience of other people, etc.

The data obtained were summarized and converted to percentage. The empirical data were quantitatively processed and analyzed at a qualitative level. Dynamics of step-by-step development of media competence was established and the obtained data are revealed in Table 1 and Table 2.

Table 1. The results of the assessment of the level of media competence in the experimental and control groups before the experimental work

\begin{tabular}{|l|c|c|c|c|c|c|}
\hline \multirow{2}{*}{ Media competence } & \multicolumn{3}{|c|}{ Experimental group } & \multicolumn{3}{c|}{ Control group } \\
\cline { 2 - 7 } & $\begin{array}{c}\text { Low level, } \\
\text { \% }\end{array}$ & $\begin{array}{c}\text { Middle } \\
\text { level, \% }\end{array}$ & $\begin{array}{c}\text { High } \\
\text { level, \% }\end{array}$ & $\begin{array}{c}\text { Low level, } \\
\text { \% }\end{array}$ & $\begin{array}{c}\text { Middle } \\
\text { level, \% }\end{array}$ & $\begin{array}{c}\text { High } \\
\text { level, \% }\end{array}$ \\
\hline Motivational component & 41,7 & 38,8 & 19,5 & 40,1 & 39,3 & 20,6 \\
\hline Cognitive component & 56,7 & 28,2 & 15,1 & 37,3 & 40,6 & 22,1 \\
\hline Technological component & 43,5 & 33,7 & 23,8 & 42,8 & 29,7 & 27,5 \\
\hline Reflective component & 57,9 & 29,7 & 12,4 & 43,4 & 35,8 & 20,8 \\
\hline
\end{tabular}

Table 2. The results of the assessment of the level of media competence in the experimental and control groups after the experimental work

\begin{tabular}{|l|c|c|c|c|c|c|}
\hline \multirow{2}{*}{ Media competence } & \multicolumn{3}{|c|}{ Experimental group } & \multicolumn{3}{c|}{ Control group } \\
\cline { 2 - 7 } & $\begin{array}{c}\text { Low level, } \\
\text { \% }\end{array}$ & $\begin{array}{c}\text { Middle } \\
\text { level, \% }\end{array}$ & $\begin{array}{c}\text { High } \\
\text { level, \% }\end{array}$ & $\begin{array}{c}\text { Low level, } \\
\text { \% }\end{array}$ & $\begin{array}{c}\text { Middle } \\
\text { level, \% }\end{array}$ & $\begin{array}{c}\text { High } \\
\text { level, \% }\end{array}$ \\
\hline Motivational component & 12,3 & 38,4 & 49,3 & 42,5 & 39,7 & 17,8 \\
\hline Cognitive component & 7,9 & 27,3 & 64,8 & 35,1 & 43,6 & 21,3 \\
\hline Technological component & 7,5 & 24,4 & 68,1 & 33,8 & 39,2 & 27,0 \\
\hline Reflective component & 4,1 & 28,3 & 67,6 & 42,3 & 37,5 & 20,2 \\
\hline
\end{tabular}


Comparative analysis of the results of input and final diagnostics of the formation of media competence of teachers in the control and experimental groups showed a significant dynamic of the development of media competence in experimental groups, which indicates the effectiveness of the experimental work.

\section{Conclusion}

A contemporary teacher should be prepared to navigate the information flow, to find necessary information, to be capable of full perception, evaluation of media texts, to understand sociocultural and political context of the functioning of media in the modern world, to code and to present systems used by media.

Growing interest to the problems of formation of media competence of future teachers is determined by the need of implementing of ICT and mobile learning technologies for developing the skills of understanding texts and processing various information.

Organization of media education process is based on the principles of problem, project and interactive learning. Various methods of teaching are based mainly on the cycles (blocks, modules) of creative educational activities.

Formation media competence of teachers contribute to implementing of main tasks of media education:

- Development of skills of analysis and synthesis of spatial and temporal reality, ability to "read" media texts of various types and genres;

- Development of media perception, that means perception of media reality, feelings and thoughts of authors of media works;

- Development of analytical skills related to the prediction of impact of media texts on various types of audiences;

- Development of interpretational skills within the process of translating media communication into the "language of individual";

- Ability to decode information of media productions, including manipulative techniques and technologies;

- Ability to develop one's own media product by means of ICT and mobile learning technologies;

- Practical skills of self-selection, creation and distribution of media texts;

- Application of knowledge gained in the field of media education for teaching and upbringing pupils and students.

Study of modern methodological and technological methods of media education, history of their emergence and development, creative use within the educational process opens new perspectives for the application of the educational and developmental potential of media education at school and university. 


\section{References}

[1] Aggor, C. S., Tchao, E. T., Keelson, E., \& Diawuo, K. (2020). Mobile phone usage among senior high and technical school students in Ghana and its impact on academic outcomes A case study https://doi.org/10.1007/978-3-030-11932-4_83

[2] Aguaded, I., Marín-Gutiérrez, I., \& Caldeiro-Pedreira, M. -. (2018). Development of media competence in the Ibero-American context. [Desarrollo de la competencia mediática en el contexto ibero-americano] Revista Letral, (20), 156-182. doi:10.30827/RL.vli20.7814 https://doi.org/10.11144/javeriana.m10-20.cmei

[3] Bond, M., Marín, V. I., Dolch, C., Bedenlier, S., \& Zawacki-Richter, O. (2018). Digital transformation in German higher education: Student and teacher perceptions and usage of digital media. International Journal of Educational Technology in Higher Education, 15(1) https://doi.org/10.1186/s41239-018-0130-1

[4] Boronenko, T. A., Kaysina, A. V., \& Fedotova, V. S. (2018). Assessment of the teacher's media-culture as the component of qualification portrait. Obrazovanie i Nauka, 20(4), 3463. https://doi.org/10.17853/1994-5639-2018-4-34-63

[5] Bubnov, Y. A., Gaidar, K. M., Fedorov, V. A., Berezhnaya, I. F., \& Galustyan, O. V. (2018). Organization of the training process based on modular and rating technology at higher educational institution. Espacios, 39(25)

[6] Burden, K., Kearney, M., Schuck, S., \& Hall, T. (2019). Investigating the use of innovative mobile pedagogies for school-aged students: A systematic literature review. Computers and Education, 138, 83-100. https://doi.org/10.1016/j.compedu.2019.04.008

[7] Elf, N. (2018). Teaching and learning modes and media of H.C. Andersen fairy tales. Forum for World Literature Studies, 10(1), 65-95

[8] Fauziah, D., Mardiyana, \& Saputro, D. R. S. (2018). The development of mini project interactive media on junior statistical materials (developmental research in junior high school). Paper presented at the Journal of Physics: Conference Series, 1013(1) https://doi. org/10.1088/1742-6596/1013/1/012120

[9] Galustyan, O. V., Berezhnaya, I. F., \& Beloshitsky, A. V. (2017). Professional and career development of teachers. Sodobna Pedagogika/Journal of Contemporary Educational Studies, 68(4), 158-172.

[10] Galustyan, O. V., Gaidar, K. M., Aleshina, S. A., Ksenofontova, A. N., \& Ledeneva, A. V. (2018). Development of group subjectivity of pupils within collaborative activities. TEM Journal, 7(4), 854-858. doi:10.18421/TEM74-25

[11] Galustyan, O. V., Lazukin, V. F., Petelin, A. S., \& Ostapenko, V. S. (2018). Diagnostic activity of teachers at high school. Espacios, 39(10)

[12] González-Fernández, N., Ramírez-García, A., \& Salcines-Talledo, I. (2018). Media competence and audiovisual literacy needs of Spanish teachers and families. [Competencia mediática y necesidades de alfabetización audiovisual de docentes y familias españolas] Educacion XX1, 21(2), 301-321. https://doi.org/10.5944/educxx1.16384

[13] Gremigni, E. (2018). Overcoming new forms of digital divide: Some remarks on the need for media education. Italian Sociological Review, 8(1), 81-102. doi:10.13136/isr.v8i1.221

[14] Hart, T., Bird, D., \& Farmer, R. (2019). Using blackboard collaborate, a digital web conference tool, to support nursing student's placement learning: A pilot study exploring its impact. Nurse Education in Practice, 38, 72-78. https://doi.org/10.1016/j.nepr.2019.05. $\underline{009}$

[15] Jacobs, H. H. (2017). Active literacy across the curriculum: Connecting print literacy with digital, media, and global competence, K-12. Active literacy across the curriculum: 
Connecting print literacy with digital, media, and global competence, K-12 (pp. 1-153). https://doi.org/10.4324/9781315693927-8

[16] Korhonen, A. -., Ruhalahti, S., \& Veermans, M. (2019). The online learning process and scaffolding in student teachers' personal learning environments. Education and Information Technologies, 24(1), 755-779. https://doi.org/10.1007/s10639-018-9793-4

[17] Kravchenko, E. V., Galustyan, O. V., Kovtunenko, L. V., \& Kolosova, L. A. (2018). Pedagogical practice of students. Espacios, 39(17)

[18] Martínez, O., Steffens, E. J., Ojeda, D. C., \& Hernández, H. G. (2018). Pedagogical strategies applied to education with virtual media for the generation of global knowledge. [Estrategias pedagógicas aplicadas a la educación con mediación virtual para la generación del conocimiento global] Formacion Universitaria, 11(5), 11-18. https://doi.org/10.4067/ s0718-50062018000500011

[19] Meza, A. Q., \& Ruíz, C. M. (2019). Evaluation of specific mathematical competences in the training of teachers of media education in Chile. [Evaluación de competencias matemáticas específicas en la formación de profesores de Educación Media en Chile] Revista Electronica Interuniversitaria De Formacion Del Profesorado, 22(1), 159-173. https://doi.org/10.6018/reifop.22.1.337261

[20] Natalie Wu, P., \& Marek, M. W. (2018). Developing intercultural competence via social media engagement in a language learning framework. Journal of Intercultural Communication, 2018(46)

[21] Nguyen, T. T. H., \& Nguyen, T. M. (2019). Information technology and teaching culture: Application in classroom doi:10.1007/978-981-13-8260-4_32

[22] Ozerbas, M. A., \& Ocal, F. N. (2019). Digital literacy competence perceptions of classroom teachers and parents regarding themselves and parents' own children. Universal Journal of Educational Research, 7(5), 1255-1264. https://doi.org/10.13189/ujer.2019.0705 $\underline{11}$

[23] Pérez-Escoda, A., García-Ruiz, R., Aguaded, I., \& Castro-Zubizarreta, A. (2017). Media literacy and digital skills for enhancing critical thinking in networked society. Paper presented at the ACM International Conference Proceeding Series, Part F132203 https://doi.org/10.1145/3144826.3145417

[24] Ranieri, M., \& Bruni, I. (2018). Digital and media literacy in teacher education: Preparing undergraduate teachers through an academic program on digital storytelling. Handbook of research on media literacy in higher education environments, 90-111. https://doi.org/ 10.4018/978-1-5225-4059-5.ch006

[25] Ranieri, M., \& Bruni, I. (2018). Promoting digital and media competences of pre-and inservice teachers. Research findings of a project from six European countries. Journal of ELearning and Knowledge Society, 14(2), 111-125. doi:10.20368/1971-8829/1497

[26] Rizal, R., Setiawan, W., \& Rusdiana, D. (2019). Digital literacy of preservice science teacher. Paper presented at the Journal of Physics: Conference Series, 1157(2) https://doi. org/10.1088/1742-6596/1157/2/022058

[27] Rodríguez, M. D. M., Méndez, V. G., \& Martín, A. M. R. (2018). Informational literacy and digital competence in teacher education students. [Alfabetización informacional y competencia digital en estudiantes de magisterio] Profesorado, 22(3), 253-270. https://doi. org/10.30827/profesorado.v22i3.8001

[28] Said, K., Kurniawan, A., \& Anton, O. (2018). Development of media-based learning using android mobile learning. Journal of Theoretical and Applied Information Technology, 96(3), 668-676.

[29] Santiago-Del Pino, M., Romero-Oliva, M. F., \& Goenechea-Permisán, C. (2019). From media to classrooms. attitudes of prospective teachers towards freedom of expression and 
participation in digital environments. [De los medios a las aulas. Actitudes de los futuros profesores de secundaria hacia la libertad de expresión y la participación en entornos digitales] Espacios, 40(2). https://doi.org/10.4185/cac51

[30] Sarmi, R. S., Ratnawulan, \& Gusnedi. (2019). Learning media analysis in the development of integrated science teacher book with theme the energy in the life using type integrated of 21st century learning. Paper presented at the Journal of Physics: Conference Series, 1185(1) https://doi.org/10.1088/1742-6596/1185/1/012080

[31] Tomé, V. (2018). Assessing media literacy in teacher education. Teacher training and professional development: Concepts, methodologies, tools, and applications, 67-85. https:// doi.org/10.4018/978-1-5225-5631-2.ch004

[32] Wang, S., Gorbunova, N. V., Masalimova, A. R., Bírová, J., \& Sergeeva, M. G. (2018). Formation of academic mobility of future foreign language teachers by means of media education technologies. Eurasia Journal of Mathematics, Science and Technology Education, 14(3), 959-976. https://doi.org/10.29333/ejmste/90556

[33] Xu, S., Yang, H. H., MacLeod, J., \& Zhu, S. (2019). Interpersonal communication competence and digital citizenship among pre-service teachers in China's teacher preparation programs. Journal of Moral Education, 48(2), 179-198. https://doi.org/10.1080/ $\underline{03057240.2018 .1458605}$

\section{$7 \quad$ Authors}

Olga V. Galustyan is Professor of the Department of Education and Pedagogical Sciences of Southern Federal University, Rostov-on-Don, Russia.

Natalia I. Vyunova is Professor of Department of Pedagogy and Pedagogical Psychology of Voronezh State University, Voronezh, Russia.

Emilia P. Komarova is Professor of Department of Foreign Languages and Translation Technologies of Voronezh State Technical University, Voronezh, Russia.

Elena S. Shusharina is Postgraduate of Department of Foreign Languages and Translation Technologies of Voronezh State Technical University, Voronezh, Russia.

Saida S. Gamisonija is Postgraduate of the Department of Education and Pedagogical Sciences of Southern Federal University, Rostov-on-Don, Russia.

Oksana N. Sklyarova is Associate Professor of Department of Foreign Languages of The Military Educational and Scientific Center of "The Air Force Academy named after Zhukovsky N.E. and Gagarin Y.A.”, Voronezh, Russia.

Article submitted 2019-07-22. Resubmitted 2019-09-10. Final acceptance 2019-09-11. Final version published as submitted by the authors. 